\title{
Analisis Tata Kelolah Dana Desa dalam Pemberdayaan Masyarakat
}

\author{
1 Petrus Peleng Roreng \\ ${ }^{2}$ Adiel Kemal Pratama \\ 1rorengp@yahoo.com \\ 1,2 Fakultas Ekonomi, Universitas Kristen Indonesia-Paulus, Makassar
}

\begin{abstract}
This research aims to understand the impact of village funds allocation in people empowerment in Bombonglambe village, Mamasa regency. This research included type of qualitative descriptive research, using primary and secondary data collected by using interviews, documentation and observation. In this research, the authors analyzing the data by collecting, reducing, and presenting the data to find the conclusion. In this research, founded that people empowerment has not been fully implemented yet in Bombonglambe village.
\end{abstract}

Keywords: village funds allocation, people empowerment

\section{Pendahuluan}

Menurut UU No. 6 tahun 2014 tentang desa, Alokasi Dana Desa paling sedikit 10\% dari dana perimbangan yang diterima kabupaten/kota dalam Anggaran Pendapatan dan Belanja Daerah setelah dikurangi Dana Alokasi Khusus. Penggunaan anggaran Alokasi Dana Desa adalah sebesar 30\% untuk belanja aparatur dan operasional pemerintahan desa, sebesar $70 \%$ untuk biaya pemberdayaan masyarakat. Dengan diterimanya dana bagi desa tersebut, pemerintah harus siap dan mampu dalam mengelola keuangan desa berdasarkan azas transparan, akuntabel, partisipatif, serta dilakukan dengan tertib dan disiplin, sesuai dengan Permendagri No. 113 tahun 2014 Tentang Pedoman Pengelolaan Keuangan Desa. Keuangan desa adalah semua hak dan kewajiban desa yang dapat dinilai dengan uang serta segala sesuatu berupa uang dan barang yang berhubungan dengan pelaksanaan hak dan kewajiban desa. Keuangan desa tersebut dikelola melalui kegiatan yang meliputi perencanaan, penganggaran, penatausahaan, pelaporan, pertanggungjawaban, dan pengawasan keuangan desa yang dilakukan oleh Kepala Desa yang dibantu oleh Pelaksana Teknis Pengelolaan Keuangan Desa.

Pada sistem pemerintahan yang ada dan berlaku saat ini, desa mempunyai peran yang sangat strategis dalam membantu pemerintah daerah dalam proses penyelenggaraan pemerintahan, termasuk pembangunan. Pembangunan pedesaan mempunyai peranan penting dalam konteks pembangunan nasional karena mencakup bagian terbesar wilayah nasional. Pelaksanaan pembangunan daerah juga bertujuan pada pemberdayaan masyarakat dan pengembangan Usaha Kecil dan Menengah di desa. Hal tersebut ditandai dengan meningkatnya anggaran pembangunan yang dialokasikan untuk kegiatan pembangunan pedesaan, baik menyangkut pembangunan fisik maupun pemberdayaan masyarakat pedesaan.

Salah satu bentuk kepedulian pemerintah terhadap pemberdayaan masyarakat desa dan pengembangan wilayah pedesaan adalah adanya anggaran pembangunan secara khusus yang dianggarkan dalam Anggaran Pendapatan dan Belanja Daerah (APBD) untuk membangun wilayah pedesaan sekaligus untuk memberdayakan masyarakat, yakni dalam bentuk pengelolaan keuangan desa. Ada beberapa alasan mengapa keberadaan ADD sangat diperlukan. Salah satu yang paling rasional adalah kebijakan ADD sejalan dengan agenda 


\section{Buana Akuntansi}

otonomi daerah, dimana desa ditempatkan sebagai basis desentralisasi. Sebagian besar masyarakat Indonesia saat ini hidup di pedesaan, sehingga desentralisasi di tingkat desa akan meningkatkan fungsi pemerintahan sesuai dengan kebutuhan masyarakatnya.

Tujuan dilakukannya penelitian ini adalah untuk mengetahui dampak yang ditimbulkan alokasi dana desa dalam pemberdayaaan masyarakat di desa Bombonglambe, serta untuk mengetahui faktor-faktor yang berpengaruh dalam pelaksanaan pemberdayaan masyarakat di desa Bombongambe. Manfaat yang diharapkan bisa didapatkan dari penelitian ini adalah bisa menjadi informasi ilmiah bagi desa Bombonglambe, sebagai bahan informasi dan tambahan literatur bagi mahasiswa yang ingin membuat karya ilmiah dengan tema yang sama, serta bagi pembaca, dapat menambah wawasan mengenai keuangan desa, terutama mengenai program-program pemberdayaan masyarakat.

Dipilihnya analisis pengelolaan dana desa karena peneliti ingin mengetahui bagaimana dampak dari dana desa terhadap pemberdayaan masyarakat. Namun untuk membenahinya, Kabupaten Mamasa memberikan Alokasi Dana Desa untuk setiap desa yang ada di Kecamatan Mamasa yang diharapkan mampu meningkatkan kesejahteraan masyarakatnya, salah satunya adalah melalui program pemberdayaan masyarakat.

\section{A. Konsep Pemberdayaan Masyarakat}

Menurut Totok dan Poerwoko (2014), pemberdayaan adalah upaya untuk memenuhi kebutuhan yang diinginkan oleh individu, kelompok dan masyarakat luas agar mereka memiliki kemampuan untuk melakukan pilihan dan mengontrol lingkungannya agar dapat memenuhi keinginan-keinginanya, termasuk aksebilitasnya terhadap sumberdaya yang terkait dengan pekerjaanya, aktivitas sosialnya, dll. Menurut Chatarina Rusmiaty (2011: 16), pemberdayaan adalah suatu cara rakyat, organisasi dan komunitas diarahkan agar mampu menguasai kehidupannya atau pemberdayaan dianggap sebagai suatu proses menjadikan orang yang cukup kuat untuk berpartisipasi terhadap kejadian-kejadian serta lembaga yang mempengaruhi kehidupannya.

Menurut Pravitasari, Soeaidy \& Hadi (2009), pemberdayaan artinya memberikan sumber daya, kesempatan, pengetahuan dan keterampilan kepada warga untuk meningkatkan kemampuan mereka dalam menentukan masa depannya sendiri dan berpartisipasi dalam mempengaruhi kehidupan dari masyarakatnya. Pemberdayaan sendiri membutuhkan sebuah proses. Menurut Agung \& Andriyani (2017), pengertian pemberdayaan sebagai suatu proses menunjuk pada serangkaian tindakan atau langkahlangkah yang dilakukan secara kronologis sistematis yang mencerminkan tahapan untuk mengubah pihak yang kurang atau yang belum berdaya menuju keberdayaan.

Jadi dapat disimpulkan, pemberdayaan masyarakat adalah proses pemberian daya terhadap perilaku dan potensi individu atau masyarakat, serta pengorganisasian kelompok masyarakat oleh pemerintah maupun masyarakat itu sendiri atas dasar partisipasi. Pemberdayaan memiliki tujuan untuk membuat masyarakat menjadi mandiri dan dapat memperbaiki segala aspek, dalam arti memiliki potensi agar mampu menyelesaikan masalah-masalah yang mereka hadapi dan sanggup memenuhi kebutuhannya, dengan tidak menggantungkan hidup mereka pada bantuan pihak luar, baik pemerintah maupun non-pemerintah.

\section{B. Prioritas Dana Desa untuk Pemberdayaan Masyarakat}

Dalam Permendes No. 22 Tahun 2016 Bab 3 pasal 7 disebutkan, dana desa digunakan untuk membiayai program dan kegiatan bidang Pemberdayaan Masyarakat Desa yang ditujukan untuk meningkatkan kapasitas dan kapabilitas masyarakat desa, 
dengan mendayagunakan potensi dan sumber dayanya sendiri, sehingga desa dapat menghidupi dirinya secara mandiri. Kegiatan pemberdayaan masyarakat desa yang diprioritaskan adalah:

a. Dukungan permodalan dan pengelolaan usaha ekonomi produktif yang dikelola oleh BUMDES dan/atau BUMDES Bersama;

b. Dukungan pengelolaan usaha ekonomi oleh kelompok masyarakat, koperasi, dan/atau lembaga ekonomi masyarakat desa lainnya;

c. Bidang pemberdayaan masyarakat desa lainnya yang sesuai dengan analisa kebutuhan desa, dan ditetapkan dalam Musyawarah Desa.

Menurut UU No. 6 Tahun 2014 Tentang Desa, yang dimaksud dengan desa adalah desa dan adat desa yang disebut dengan nama lain, selanjutnya disebut desa, adalah kesatuan masyarakat hukum yang memiliki batas wilayah yang berwenang untuk mengatur dan mengurus urusan pemerintahan, kepentingan masyarakat berdasarkan prakarsa masyarakat, hak asal-usul, dan/atau hak tradisional yang diakui yang dihormati dalam sistem pemerintahan Negara Kesatuan Republik Indonesia.

\section{Keuangan Desa}

Keuangan desa adalah semua hak dan kewajiban dalam rangka penyelenggaraan pemerintahan desa yang dapat dinilai dengan uang, termasuk di dalamnya segala bentuk kekayaan yang berhubungan dengan hak dan kewajiban desa tersebut. Keuangan desa dikelola dengan azas-azas transparan, akuntabel, partisipatif serta dilakukan dengan tertib dan disiplin anggaran. Menurut UU No. 6 Tahun 2014 Tentang desa, pendapatan desa bersumber dari:

a. Pendapatan asli desa, terdiri atas hasil usaha, hasil aset, swadaya dan partisipasi, gotong royong, dan lain-lain pendapatan asli desa,

b. Alokasi Anggaran dan Belanja Negara,

c. Bagian dari hasil pajak daerah dan retribusi daerah Kabupaten/Kota,

d. Alokasi dana desa yang merupakan bagian dana perimbangan yang diterima Kabupaten/Kota,

e. Bantuan keuangan dari Anggaran Pendapatan dan Belanja Daerah provinsi, dan Anggaran Pandapatan dan Belanja Daerah Kabupaten/Kota,

f. Hibah dan sumbangan yang tidak mengikat dari pihak ketiga, serta

g. Pendapatan lain-lain desa yang sah.

Penyaluran ADD dan bagian dari hasil pajak daerah dan retribusi daerah kabupaten/kota dari kabupaten/kota ke desa dilakukan secara bertahap. Pelaporan dan pertanggungjawaban ADD dilakukan oleh kepala desa dengan menyampaikan Laporan Realisasi Pelaksanaan APBDesa kepada bupati/walikota setiap semester tahun berjalan. Laporan untuk semester pertama disampaikan paling lambat akhir bulan Juli tahun berjalan, sedangkan laporan untuk semester kedua disampaikan paling lambat pada akhir bulan Januari tahun berikutnya. Selain penyampaian Laporan Realisasi Pelaksanaan APB Desa, kepala desa juga menyampaikan Laporan Pertanggung jawaban Realisasi Pelaksanaan APB Desa kepada bupati/walikota setiap akhir tahun anggaran. Laporan yang dimaksud merupakan bagian yang tidak terpisahkan dari laporan penyelenggaraan Pemerintahan Desa kepada bupati/walikota melalui camat atau sebutan lain setiap akhir tahun anggaran. 


\section{Metode Penelitian}

Jenis penelitian ini adalah dengan pendekatan kualitatif dan sumber data/informasi adalah informan penelitian maka metode penetapan informan penelitian digunakan dengan menggunakan metode Purposive Teknik, yaitu metode penentuan informan yang sesuai dengan karakteristik yang ditentukan yang ditentukan antyara lain : Kepala Desa, Anggota BPD, Anggota LKD dan Masyarakat. Serta instansi Pemerintah daerah yang terkait seperti kepala BMPD dan camat pada wilayah penelitian. Teknik analisis data yang digunakan dalam penelitian ini adalah sebagai berikut:

a. Wawancara yaitu bertanya secara langsung kepada informan penelitian yang berdasarkan pada pedoman wawancara dan kebutuhan informasi yang dikembangkan.

b. Observasi yaitu dengan mengamati langsung proses kegiatan di lokasi yang menjadi yang menjadi objek penelitian.

c. Studi dokumentasi yaitu proses pengumpulan data dengan mempelajari atau menganalisis seluruh dokumen yang berhubungan dengan penelitian.

\section{Hasil Penelitian Dan Pembahasan}

\section{A. Dampak Dana Desa Dalam Pemberdayaan Masyarakat di Desa Bombonglambe}

Akuntabilitas adalah suatu keharusan oleh pemerintah desa sebagai administrasi pembangunan sekaligus pengelolah keuangan terhadap masyarakat yang menjadi penerima manfaat atau kelompok sasaran. Tujuan dari prinsip akuntabilitas ini adalah menjaga ketidakjelasan mengenai penggunaan dana desa yang diperuntukkan bagi pemberdayaan masyarakat. Dikatakan demikian karena kepuasan masyarakat harus terpenuhi, maka diperlukan pihak pemegang amanah untuk memberikan pertanggungjawaban, menyajikan dan mengungkapkan segala aktifitasnya, dan kegiatan yang menjadi tanggungjawab kepada kelompok sasaran, yakni masyarakat.

Hal tersebut diatas sesuai apa yang dikatakan oleh salah seorang informan, Anna Martince, yang mengatakan bahwa:

"Sebenarnya mekanisme pengelolaan serta pemanfaatan alokasi dana desa perlu dilaporkan pada masyarakat yang ada di desa ini. Pemerintah desa kita juga harus melakukan pertanggungjawaban atau pelaporan tentang program apa saja yang telah dan akan dilaksanakan dengan menggunakan dana desa, sehingga masyarakat dapat mengetahuinya".

Dapat dikatakan bahwa masyarakat belum diberdayakan secara optimal dalam pemanfaatan Alokasi Dana Desa di desa Bombonglambe'. Dana yang digunakan baru hanya sekitar 26\%. Sedangkan seperti yang telah dijelaskan di latar belakang sebelumya, pengalokasian dana desa untuk program pemberdayaan masyarakat seharusnya sebanyak $70 \%$. Selain itu, dalam tabel APBDes di atas, dapat terlihat bahwa belum ada kegiatan yang memberdayakan masyarakat. Hal ini mungkin disebabkan karena kurang kreatifnya pemerintah desa dalam mengelola dana desa yang telah dipercayakan kepada mereka, sehingga mereka belum mampu menciptakan kegiatan-kegiatan yang bisa memberdayakan masyarakat.

Belum adanya kegiatan yang benar-benar memberdayakan masyarakat adalah salah satu persoalan yang membuat pengalokasian dana desa untuk pemberdayaan masyarakat tidak sesuai dengan peruntukannya. Dana yang seharusnya digunakan untuk mengembangkan dan menggali potensi masyarakat desa, malah digunakan untuk bidang lain yang tidak ada hubungannya dengan pemberdayaan masyarakat secara langsung. Padahal bisa dikatakan bahwa masyarakat desa Bombongambe memiliki potensi yang cukup menjanjikan, misalnya saja pengarajin tenun. Selain itu, rendahnya kualitas pendidikan dan banyaknya anak yang putus sekolah seharusnya menjadi dasar bagi 


\section{Buana Akuntansi}

pemerintah desa untuk membentuk program/kegiatan yang dapat memberdayakan mereka. Tidak dibentuknya Prukades dan BUMDes juga merupakan salah satu kegagalan pemerintah desa dalam mengalokasikan dana desa sesuai dengan peraturan yang berlaku.

\section{A.1.Pengelolaan Alokasi Dana Desa Di Desa Bombonglambe}

\section{a. Perencanaan Alokasi Dana Desa.}

Proses perencanaan ADD dimulai dengan menjaring aspirasi masyarakat atau kebutuhan masyarakat melalui musyawarah desa. Di desa Bombonglambe, musyawarah desa dilakukan dengan membahas Anggaran Pendapatan dan Belanja Desa (APBDes), serta Musyawarah Rencana Pembangunan Desa (Musrembang), sehingga dihasilkan Rencana Penggunaan Dana (RPD). Dalam kegiatan Musrembang ini tentunya dibutuhkan pasrtisipasi masyarakat yang tinggi, agar segala ide dan gagasan masyarakat desa dapat ditampung dan menjadi bahan pertimbangan pemerintah desa dalam menetukan seberapa besar anggaran yang akan diperuntukkan bagi pemberdayaan masyarakat. Sesuai dengan wawancara dengan salah seorang tokoh masyarakat di desa, Andarias:

"Kegiatan perumusan program desa dengan ikut melibatkan masyarakat adalah salah satu langkah yang tepat yang dilakukan oleh pemerintah kita. Karena melalui kegiatan itulah, masyarakat desa dapat menyampaikan aspirasi mereka".

b. Mekanisme penyaluran Alokasi Dana Desa.

Peraturan Bupati No. 39.a tahun 2016 tentang Tata Cara Pembagian dan Penetapan Rincian Alokasi Dana Desa Setiap Desa di Kabupaten Mamasa Tahun Anggaran 2017, Bab 3 mengenai Penyaluran Alokasi Dana Desa, mekanisme penyaluran alokasi dana desa dilakukan dalam beberapa tahap. Penyaluran ADD dilakukan apabila sudah ditetapkan dalam Peraturan Desa tentang Anggaran Pendapatan dan Belanja Desa (APBDes). Penyaluran dilakukan dengan cara pemindahbukuan dari RKUD ke Rekening Kas Desa. Penyaluran tersebut dilaksanakan secara bertahap melalui bank yang ditunjuk dalam dua tahap:

- Tahap I sebesar $60 \%$ (enam puluh perseratus) pada bulan Maret, dan

- Tahap II sebesar 40\% (empat puluh perseratus) pada bulan Agustus.

Penyaluran Alokasi Dana Desa tahap pertama dilakukan setelah kepala desa menyampaikan:

a. Peraturan Desa mengenai APBDes kepada Bupati Kabupaten Mamasa,

b. Realisasi penggunaan Alokasi Dana Desa dan Laporan pertanggungjawaban tahun anggaran sebelumnya kepada bupati Mamasa paling lambat minggu kedua bulan Februari.

Penyaluran alokasi dana desa tahap kedua dilakukan setelah kepala desa menyampaikan laporan realisasi penggunaan alokasi dana desa tahap pertama telah digunakan sebesar 80\% kepada bupati Mamasa, melalui Dinas Pemberdayaan Masyarakat dan Pemerintahan Desa paling lambat minggu keempat bulan Juli.

Setelah penyampaian pelaporan telah selesai dilaksanakan, maka usulan pengajuan penyaluran diterima dan dihimpun oleh Dinas Pemberdayaan Masyarakat dan Pemerintahan Desa, kemudian mengajukan permohonan transfer dari Rekening Kas Umum Daerah ke Rekening Kas Desa yag dilakukan setiap hari Senin. Dinas Pengelola Keuangan dan Aset Daerah kemudian melakukan verifikasi akhir sesuai dengan peraturan perundangan yang berlaku.

c. Penggunaan ADD

Penggunaan ADD untuk pemberdayaan masyarakat di desa Bombonglambe adalah sebesar Rp. 201.968.000. Dalam penggunaannya, dana desa bidang pemberdayaan 
masyarakat telah digunakan untuk mengadakan pelatihan kepala desa, perangkat desa, dan BPD, serta telah digunakan juga untuk peningkatan kapasitas lembaga masyarakat.

Dalam penggunaan dana untuk peningkatan derajat kesehatan yaitu dengan memberikan bantuan kepada Pos Pelayanan Terpadu (Posyandu). Dimana dana tersebut digunakan untuk membiayai kegiatan-kegiatan posyandu balita maupun pustu. Hal ini sesuai dengan teori pemberdayaan oleh Ife dalam Suharto (2005, h.59), yang mengatakan bahwa pemberdayaan dapat dilihat dari kemampuan dalam kaitannya dengan proses kelahiran dan perawatan anak.

Berdasarkan teori pemberdayaan masyarakat oleh Ife dalam Suharto (2005, h.55), yang menjelaskan bahwa pemberdayaan masyarakat dapat dilakukan dengan meningkatkan kemampuan menjangkau, menggunakan, dan mempengaruhi pranatapranata masyarakat, seperti lembaga kesejahteraan sosial, pendidikan, kesehatan. Pada bidang pendidikan, penggunaan dana desa untuk peningkatan pendidikan luar sekolah yaitu dengan memberikan bantuan untuk operasional kegiatan belajar mengajar TK dan PAUD. Dalam pemanfaatannya sebenarnya sudah sesuai, mengingat tingkat pendidkan di desa Bombonglambe masih cukup rendah, yaitu mayoritas lulusan SD dan SMP. Namun bisa dikatakan bahwa dana yang dialokasikan tidak cukup, sehingga hal inilah yang akan menjadi penghambat dalam meningkatkan kualitas pendidkan. Menurut peneliti, alangkah baiknya jika pemerintah desa meningkatkan anggaran untuk pendidikan, dan menggunakannya untuk menunjang kegiatan-kegiatan pendidikan selain sekolah, seperti pendidikan dan pelatihan kelompok-kelompok tani.

Pengalokasian dana desa dalam pembangunan infrastruktur desa dengan melibatkan masyarakat sudah dilakukan. Dalam penggunaannya, anggaran pembangunan pedesaan diperuntukkan untuk membangun dan memelihara sarana publik, yaitu pembangunan jalan desa, yang menghubungkan dusun Kilo Meter Lima dan dusun Bombonglambe. Dalam pengalokasian untuk seluruh program kerja, dana untuk pembangunan jalan desa dalah yang paling banyak, yakni sebanyak $70 \%$, mengingat jalan desa yang ada di desa Bombonglambe masih banyak yang rusak, dan perlu dilakukan betonisasi. Penggunaan dana desa untuk pembangunan infrastruktur tersebut sesuai dengan pendapat Widjaja (2004, h.69) yang mengatakan bahwa pendukung berkembangnya potensi masyarakat melalui peningkatan peran, produktivitas dan efisiensi serta dapat memperbaiki empat akses, yaitu akses terhadap sumber daya, akses terhadap sumber teknologi, akses terhadap pasar, dan akses terhadap sumber pembiayaan.

Penggunaan dana desa di desa Bombonglambe memang cukup memberikan dampak positif terhadap peningkatan kegotong-royongan masyarakat maupun dalam pembangunan sarana dan prasarana desa. Namun, ada pula dampak negative dari keberadaan dana desa ini, yaitu timbulnya ketergantungan desa terhadap dana tersebut, sehingga upaya pemerintah desa untuk mendapat sumber keuangan sendiri berangsurangsur memudar. Di desa Bombong lambe, penggunaan alokasi dana desa sudah cukup berjalan dengan baik, walaupun dalam berbagai bidang penggunaan alokasi dana desa belum optimal. Hal ini bisa dilihat dari rendahnya swadaya masyarakat, yang seharusnya menjadi Pendapatan Asli Desa, dan belum terbentuknya Badan Usaha Milik Desa (BUMDes) dan Prukades.

\section{d. Pertanggungjawaban Pengalokasian Dana Desa}

Pertanggungjawaban merupakan bentuk konsekuensi atas penggunaan dana publik yang dipercayakan kepada pemerintah desa. Sesuai dengan PerBup Mamasa No. 30.a tahun 2016 tentang Tata Cara Pembagian Dan Penetapan Rincian Alokasi Dana Desa bab V 
tentang Pelaporan Alokasi Dana Desa, diakatakan bahwa pelaporan perlu dilakukan dalam rangka untuk pengendalian dan untuk mengetahui perkembangan proses pengelolaan dan penggunaan dana dari alokasi dana desa. Jika kepala desa tidak atau terlambat menyampaikan laporannya, maka bupati dapat menunda penyaluran dana desa sampai dengan disampaikannya laporan realisasi penggunaan alokasi dana desa.

Tahap pertama yang dilakukan dalam proses pelaporan adalah kepala desa, dengan dikoordinasikan dengan camat setempat menyampaikan laporan realisasi penggunaan alokasi dana desa tahap pertama, dan laporan realisasi penggunaan alokasi dana desa tahunan kepada bupati Mamasa, melalui Dinas Pemberdayaan Masyarakat dan Pemerintahan Desa. Penyampaian laporan realisasi penggunaan Alokasi Dana Desa dilakukan dengan ketentuan:

a. Tahap pertama paling lambat minggu keempat bulan Juli tahun anggaran berjalan,

b. Laporan realisasi Alokasi Dana Desa tahunan paling lambat minggu keempat bulan Januari tahun anggaran berikutnya.

Kurang efektifnya penggunaan dana desa di desa Bombonglambe' menunjukkan adanya kelemahan dalam pengelolaannya. Pertama, kepala desa sebagai pemegang kekuasaan dalam pengelolaan kekuasaan desa terlalu banyak berperan dalam proses penganggaran, sehingga menyebabkan kurang efektifnya kerjasama tim dalam menyusun RPJMDesa dan melaksanakan APB Desa berdasarkan prinsip akuntabilitas dan transparansi.

Kedua, jajaran pemerintah desa terutama bendahara desa tidak memahami dengan baik regulasi dan kebijakan dalam mengelola dana desa, sehingga pemahaman pengelolaan dana desa hanya terbatas pada pengajuan pencairan dana desa, perumusan alokasi penggunaan dana desa, dan pelaporan administratif. Dari kasus ini, maka dapat diketahui bahwa jajaran pemerintah desa Bombonglambe' tidak memahami substansi dana desa sebagai media dalam menguatkan kinerja pemerintahan desa, dan terutama serangkaian program pemberdayaan masyarakat.

Ketiga, dalam pelaksanaan Musrembang di desa Bombonglambe', gagasan-gagasan yang diberikan masyarakat hanya fokus pada pembangunan fisik seperti perbaikan jalan raya dan fasilitas sarana dan prasarana desa, bukan gagasan tentang program-program yang dapat dilaksanakan untuk memberdayakan masyarakat desa, sehingga dapat dikatakan bahwa partisipasi masyarakat dalam mendukung pemberdayaaan masyarakat belum efektif.

Dari uraian yang telah disebutkan di atas, maka pemerintah desa harus lebih meningkatkan kefektifitasan dan efisiensi penggunaan dana desa dengan cara meningkatkan kerjasama tim dalam jajaran pemerintahan dana desa, memperhatikan pedoman pelaksanaan pengelolaan dana desa, pendampingan, pengembangan database, dan menetapkan target keberhasilan. Pengembangan kapasitas sumber daya manusia melalui pendidikan, pelatihan, dan pemagangan juga perlu dilakukan. Selain itu, penggunaan dana desa seharusnya sesuai apa yang tertuang dalam RPJMDesa yang kemudian digunakan sebagai pedoman dalam menyusun APBDesa, agar terjadi kesinambungan antara perencanaan dengan pelaksanaan selama masa pemerintahan jajaran pemerintah desa Bombonglambe'. 


\section{A2. Faktor-Faktor yang Mempengaruhi Pelaksanaan Pemberdayaan Masyarakat}

Ada beberapa faktor yang mempengaruhi pelaksanaan pemberdayaan masyarakat di desa Bombonglambe:

\section{Faktor Pendukung}

a. Peran serta masyarakat dan lembaga organisasi masyarakat pedesaan.

Di dalam pemberdayaan masyarakat yang penting adalah bagaimana menjadikan masyarakat pada posisi pelaku pembangunan yang aktif, bukan penerima yang pasif. Masyarakat yang lebih mengenal kebutuhan dan permasalahannya harus lebih diberdayakan agar masyarakat bisa lebih mampu mengenali potensi diri mereka sendiri dan dapat memenuhi kebutuhan mereka sendiri.

b. Dana

Dana yang dikucurkan dari kabupaten bisa dikatakan sangat cukup untuk memberdayakan masyarakat, untuk desa dengan luas hanya $10,5 \mathrm{~km}^{2}$, hanya saja pemerintah desa tidak mengelola nya sesuai dengan pedoman pengelolaan keuangan desa yang benar dan peraturan yang berlaku.

\section{Faktor Penghambat}

a. Kurangnya kreativitas dalam mengelola dana desa

Pada proses perencanaan ADD di desa Bombonglambe menerapkan system musyawarah desa. Dalam proses musyawarah, terlihat bahwa partisipasi masyarakat tinggi, namun bentuk-bentuk usulan kegiatan dari masyarakat masih cenderung bersifat pembangunan fisik, seperti perbaikan jalan, irigasi, dan lain-lain. Padahal kegiatan tersebut tidak bersifat pemberdayaan pada diri masyarakat sendiri. Ide-ide pemberdayaan yang seharusnya diusulkan oleh masyarakat adalah kegiatan yang bisa meningkatkan tingkat swadaya masyarakat, karena swadaya masyarakat adalah Pendapatan Asli Desa (PADes) yang sah. Kurangnya swadaya masyarakat merupakan cerminan dari tingkat kesejahteraan masyarakat desa yang dinilai masih kurang sejahtera. Padahal dalam Permendagri No. 113 tahun 2014 tentang Pedoman Pengelolaan Keuangan Desa, dikatakan bahwa salah satu tujuan dana desa adalah meningkatkan swadaya masyarakat.

b. Kurangnya sosialisasi di desa

Sosialisasi adalah salah satu langkah yang dapat digunakan untuk menambah pengetahuan, terutama diperuntukkan bagi para pegawai desa, mengenai system yang dapat mendukung pelaksanaan pemerintahan di desa. Di desa Bombonglambe, masih ada beberapa orang pegawai yang belum mahir mengoperasikan alat elektronik komputer. Padahal, dalam Peraturan Bupati Mamasa Tentang Pedoman Pengelolaan Keuangan Desa bab 3 mengenai pengelolaan keuangan desa, dikatakan bahwa "pengelolaan keuangan desa wajib menggunakan aplikasi system keuangan desa (SisKeuDes)".

\section{Kesimpulan Dan Saran}

\section{A.Kesimpulan}

Berdasarkan uraian pada bab-bab sebelumnya, maka dapat ditarik beberapa kesimpulan yang merupakan jawaban terhadap permasalahan yang telah disusun:

a. Berdasarkan hasil penelitian, pengalokasian dana desa terhadap pemberdayaan masyarakat di desa Bombonglambe belum teralokasikan dengan baik, karena pengalokasian dana desa tidak sesuai dengan peruntukannya. 


\section{Buana Akuntansi}

b. Pemerintah desa belum memanfaatkan dana desa secara efektif, sehingga program pemberdayaan masyarakat pun belum terlaksana dengan semestinya.

\section{B. Saran}

Berdasarkan hasil kesimpulan dari penelitian yang telah dijelaskan sebelumnya, maka peneliti menyampaikan saran-saran sebagai berikut:

a. Pemerintah desa harus lebih sering melakukan pelatihan-pelatihan terhadap pegawaipegawai yang ada dalam jajaran pemerintahan desa Bombonglambe, diantaranya penyusunan Renstra Desa dan tata Kelolah keuangan agar program pemberdayaan masyarakat tepat sasaran.

b. Pemerintah desa harus lebih meningkatkan efektivitas pengelolaan dana desa, agar anggaran yang ada dapat digunakan sesuai substansinya, terutama dalam hal pemberdayaan masyarakat. 


\section{DAFTAR PUSTAKA}

Agung, A., \& Andriyani, I. (2017). Pemberdayaan Masyarakat Melalui Pengembangan Desa Wisata Dan Implikasinya Terhadap Ketahanan Sosial Budaya Wilayah ( Studi Di Desa Wisata Penglipuran Bali ), 9340, 1-16.

Chatarina Rusmiyati. 2011. Pemberdayaan Remaja Putus Sekolah. Yogyakarta: B2P3KS

Pravitasari, S. E., Soeaidy, M. S., \& Hadi, M. (2009). Guna Meningkatkan Kualitas Sumber Daya Manusia ( Studi Pada UPT Rehabilitasi Sosial Cacat Netra Malang ), 2(1), 53-59.

Totok dan Poerwoko. 2012. Pemberdayaan Masyarakat dalam Prespektif Kebijakan Publik. Bandung: Alfabeta.

. (2017). Peraturan Bupati Mamasa Tentang Tata Cara Pembagian dan Penetapan Rincian Alokasi Dana Desa Setiap Desa di Kabupaten Mamasa Tahun Anggaran 2017. Mamasa.

2014. Undang-Undang No. 6 tahun 2014 tentang desa, Jakarta.

2014. Permendagri No. 113 Tahun 2014 Tentang Pengelolaan Keuangan Desa . 2016. Permendes No. 22 Tahun 2016 Bab 3 pasal 7 tentang Bidang Pemberdayaan Masyarakat, Jakarta. 